\title{
GENETIC CHARACTERIZATION OF HONEY BEES (Apis mellifera) IN THE DRY COASTAL ZONE OF THE O'HIGGINS REGION, CHILE
}

\author{
CARACTERIZACIÓN GENÉTICA DE LA ABEJA DE MIEL (Apis mellifera) EN \\ LA ZONA COSTERA DE LA REGIÓN DE O’HIGGINS, CHILE
}

\author{
Nicolás F. Barriga ${ }^{1}$, Naomi M. Durán ${ }^{2 *}$, Patricia L. Aldea ${ }^{2}$ \\ ${ }^{1}$ Escuela de Medicina Veterinaria, Facultad de Ciencias, Universidad Mayor, Camino La Pirámide 5750, \\ Huechuraba, Santiago, Chile. nicolas.barriga@umayor.cl. \\ ${ }^{2}$ Centro de Estudios Apícola (CEAPIMAYOR), Facultad de Ciencias, Universidad Mayor, Camino La \\ Pirámide 5750, Huechuraba, Santiago, Chile. \\ *Corresponding author E-mail: naomi.duran@mayor.cl
}

\begin{abstract}
The natural diversity of the honey bee (Apis mellifera) includes five evolutionary lineages and 26 subspecies, currently described that come from Africa, Europe, and the Middle East. They were introduced by humans to almost every continent and each of them has adapted favorably to the environmental and climatic conditions of their geographical areas of origin, which has led to greater genetic diversity and hybridization processes between subspecies. The genetic diversity of honey bees in Chile was characterized by the presence of European subspecies, such as Apis mellifera mellifera and Apis mellifera ligustica, but no updated information is available. The objective of this study was to assess the current genetic characterization of honey bees in the coastal zone of the O'Higgins Region, due to its national importance in beekeeping, using geometric morphometrics. Samples were taken from five counties taking samples of five apiaries from each one, including 3 colonies per apiary with a total of 30 bees per colony. The results indicate that there is evidence of hybridization between the subspecies Apis mellifera carnica and Apis mellifera ligustica, which reveals that the genetic pattern of the region has changed. This raises the questions as to whether this hybridization with predominantly Apis mellifera carnica is the most suitable for the ecological conditions of the region and how this could affect colony productivity and local beekeeping.
\end{abstract}

Key words: lineage, subspecies, morphometry, honey bee, Apis mellifera

\section{INTRODUCTION}

The genus Apis has its origin in tropical and subtropical zones of Asia and then moved to Africa and later to Europe, where it was domesticated centuries ago (Ruttner, 1988). Honey bees are now widespread across Africa, Asia, Europe, America, and Oceania. All honey bee subspecies are divided into five main lineages that are described according to their place of origin (Ruttner, 1988; Dogantzis and Zayed,
2019). The first ones described were the African lineage $(\mathrm{A})$, the Western and Northern Europe lineage $(\mathrm{M})$, and the Eastern Europe lineage $(\mathrm{C})$ (Ruttner, 1988). Then the Middle East and West Asia lineage (O) was described (Ruttner, 1988) and later, the East African lineage $(\mathrm{Y})$ (Franck et al., 2000).

The subsequent adaptation of the described lineages of honey bees (Apis mellifera) to a wide variety of ecological conditions resulted in the evolution of 26 subspecies (Ruttner,

Received: 30 August 2020. Accepted: 29 October 2020. 
1988; Franck et al., 2000), which are found in all continents. Adaptation to such variety of habitats, climatic conditions, and flora allowed honey bees developing different characteristics (Büchler et al, 2014). They have been moved all over the world for beekeeping, changing the natural range of each one, and leading to a process of hybridization between them (De la Rúa, 2009). As such, these subspecies depend on the climatic conditions that they have been subjected to, their biological interactions, and on human intervention in influence the selection of breeding lines (Büchler et al, 2014). Significant differences in collection strategies and honey storage emerged as a result of adaptation over millennia to the environments where each lineage and subspecies have developed under a selection pressures (Taha and AL-Kahtani, 2017). Taha and AL-Kahtani (2017) indicated that related existing subspecies with their own climate adaptation characteristics would improve productivity since they respond better in a habitat equal or similar to that of their original lineage. Moreover, the Agricultural and Livestock Service (SAG, 2018) has indicated that honey bee subspecies perform differently in different regions. This is why it is recommended to have genotype queens that are well adapted to the ecological conditions where they are intended to be used.

The introduction of the honey bee in South America occurred at the end of the 18th century, first in Brazil, and then in the rest of the countries where the subspecies Apis mellifera mellifera and Apis mellifera iberica were introduced (Padilla et al., 1992). The subspecies Apis mellifera ligustica was later imported from Italy (Padilla et al., 1992) due to its high production levels, docility, and adaptability to varying climates, particularly Mediterranean climates (SAG, 2018). In 1884, colonies of Apis mellifera mellifera were introduced to Chile and Peru (Del Lama et al., 2004), indicating that these bee populations in Chile were of particular interest since they were the result of frequent introductions of European subspecies over the time. In 1984, the first imports of the subspecies Apis mellifera carnica from Canada to Chile occurred (Rey and Díaz, 2007). The aforementioned subspecies originated in Slovenia and Yugoslavia and exhibits mild behavior, good brood production in spring, good honey accumulation in summer, and can also adapt to diverse climates, especially cold winters (Ruttner, 1988; Susnik et al., 2004; SAG, 2018). Accordingly, Del Lama et al. (2004) found that the genetic status of Chilean bees between 1997 and 2001 mostly comprised the M lineage and the most common subspecies found were Apis mellifera mellifera and Apis mellifera ligustica. Likewise,
Vidal (2012) conducted the latest genetic study of the country in different regions and showed that the populations studied in Chile, including the $\mathrm{O}^{\prime}$ Higgins Region, were made up of the lineages $\mathrm{C}$ and $\mathrm{M}$, with Apis mellifera ligustica and Apis mellifera mellifera as the leading subspecies.

The Office of Agricultural Studies and Policies (ODEPA, 2015) indicated that an accurate understanding of the national product, in terms of queen genetics, could improve the marketing strategy of biological material, which is important because the country was established as an exporter in 2013 (ODEPA, 2013). Chile is one of the four countries authorized to export queen bees and bee packages to Canada (ProChile, 2018). This is due to the high demand for biological material after the Canadian winter (ProChile, 2018) and the health status of honey bees in Chile because of its geographical conditions (Del Lama et al., 2004; Rey and Díaz, 2007), which frees them from the Africanization gene (ProChile, 2018; Dogantzis and Zayed, 2019) and the small hive beetle (OIE, 2019). Canadians are interested in queen bees from Chile for various reasons, such as their genetic line (carnica queens), gentleness, disease resistance, adaptability to climatic changes, and their rapid production of broods in spring (ProChile, 2018).

The three main activities that characterize apiculture in the $\mathrm{O}^{\prime}$ Higgins Region are honey production, pollination services, and breeding of queens and biological material, which are marketed inside and outside the region (SAG, 2019). The Beekeeping Bulletin No. 4 (SAG, 2019) reported that the $\mathrm{O}^{\prime}$ Higgins Region is ranked third in terms of the number of beekeepers in Chile, first in the number of beehives, and fifth in the number of queen breeders (SAG, 2019). As such, the O'Higgins Region is one of the most important regions in beekeeping production. However, there has been a historical trend to reduce honey production at the national level. This can also be extrapolated to the region as volumes of honey exports declined considerably from 9,888 tons in 2015 to 5,212 tons in 2017 (ODEPA, 2018). It is important to note that the O'Higgins Region is ideal for developing exceptional beekeeping due to its climatic advantages (Rey and Díaz, 2007), a characteristic that is especially beneficial for queen breeding, since nuptial flight only occurs in optimal climates (Morse, 1994)

It is important to understand that changes in the genetic composition of resident populations, derived from the introduction of honey bees in different geographical areas, requires tools to differentiate the different lineages (Del Lama, 2004). There are three main methods for identifying lineages and subspecies (Tofilski, 
2008; Miguel et al., 2010), which include traditional morphometrics (Ruttner, 1988), geometric morphometrics (GM) (Tofilski, 2008), and molecular biology through DNA analysis (Olekza and Tofilski, 2014). According to Tofilski (2008) and Barour et al. (2011), GM is a relatively new method based on the study of honey bee wing shape through its venation patterns, allowing for the identification of lineages and subspecies through a low-cost technique, which is easily accessible to beekeepers while eliminating measurement errors that are common in linear morphometry (Klingenberg, 2011).

The objective of this study was to assess the current Apis mellifera subspecies characterization in the dry coastal zone of central Chile by studying the wing shape of the honey bee using GM as a technique, since no such studies have been performed at the national level. This is also an initial study to provide an updated and better understanding of the genetics described above. It also focuses on whether there is a relationship between productivity and survival losses of honey bee colonies within the lineages and subspecies of queens used in the region.

\section{MATERIALS AND METHODS}

\section{Study area and sample size}

Sampling was carried out in 5 counties of the dry coastal zone of the O'Higgins Region: Pichilemu (23'31" S; 720'34" O), Marchigue

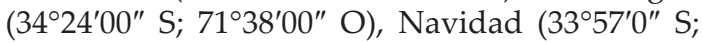
$\left.71^{\circ} 49^{\prime} 60^{\prime \prime} \mathrm{O}\right)$, La Estrella $\left(34^{\circ} 12^{\prime} 00^{\prime \prime} \mathrm{S} ; 71^{\circ} 40^{\prime} 00^{\prime \prime}\right.$ O), and Paredones ( $34^{\circ} 47^{\prime} 00^{\prime \prime}$ S; $\left.71^{\circ} 10^{\prime} 00^{\prime \prime} \mathrm{O}\right)$.

Both sampling and sample size were carried out according to the recommendations of Bouga et al. (2011), who indicate that five apiaries per geographical area should be sampled in order to keep sampling errors within tolerable limits. A total of 25 fixed apiaries were sampled (5 from each of the five counties), i.e., random samples and those that did not perform transhumance. From each apiary, 3 colonies were sampled, and 30 worker bees were obtained from the brood chambers of each colony. The sampling period was between August and September 2018 (spring season). The study was reviewed and approved by the Bioethic Committee of the Universidad Mayor.

\section{Experimental design}

From each sample collected, the right anterior wings of 15 bees were dissected and soaked in $70 \%$ alcohol in the laboratory of the Center for Bee Research of the University Mayor (CEAPIMAYOR). They were then neatly arranged on a slide and a $2592 \times 1944$ pixel photograph was taken of each dissected wing using a magnifier (AmScope, MU500 model, Tustin, California, USA) at $4 x$ magnification before the image was then uploaded into the TpsDig232® software. 19 landmarks were measured at the intersections of the wing veins in each wing (Fig. 1). TpsUtil64® was used to acquire and appended the information in TPS format, in a dataset used in MorphoJ® version 2.0 (Klingenberg, 2011).

\section{Statistical analysis}

Morpho J® version 2.0 calculated the covariation between sampled and reference wings of six $A$. mellifera subspecies, representing 50 different colonies (Apis mellifera carnica, Apis mellifera iberica, Apis mellifera intermissa, Apis mellifera ligustica, Apis mellifera mellifera, and Apis mellifera scutellata) obtained from the Morphometric Bee Data Bank in Oberursel, Germany. These six pure subspecies images were

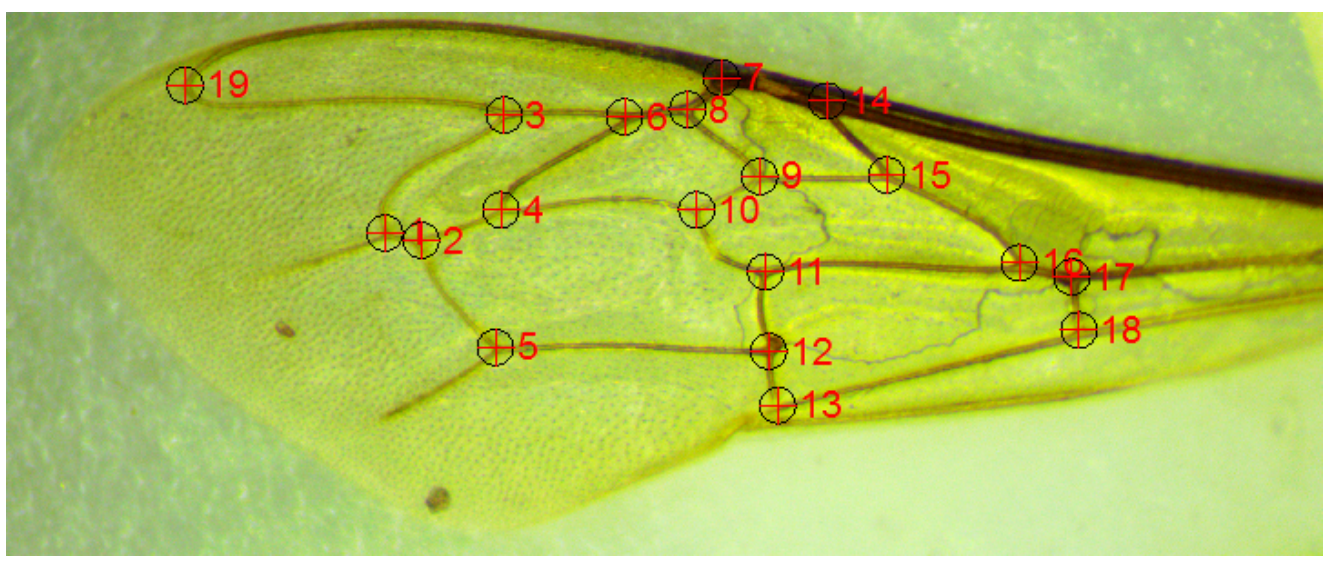

Fig. 1. Total of 19 landmarks at the intersections of the wing veins. Source: Author elaboration in Morpho J ${ }^{\circledR}$ software. 
previously classified by molecular methods and were obtained in collaboration with the Social Bee Research Center (CIAS), National University of Mar del Plata, Argentine. Multivariate statistical analysis of the data included the Canonical variate analysis (CVA), which delivers Mahalanobis distances and CVA scatter plots as results. The geometric morphometric analysis consists of three fundamental stages: i) obtaining the primary data through the coordinates $(\mathrm{x}, \mathrm{y})$ from each landmark arranged in the wings, ii) obtaining the shape variables, and iii) a statistical analysis through the study of main components or CCA (Toro et al., 2010). It is also a tool used to objectively evaluate shape variations (Toro et al., 2010). Data were analyzed at a significance level of $10 \%$

\section{RESULTS}

The results obtained by GM analysis of samples from the coastal zone of the O'Higgins Region indicated that there was hybridization between the subspecies Apis mellifera carnica and Apis mellifera ligustica, since the variation patterns of the venous branches of the wing had the smallest and almost the same Mahalanobis distances for both with a slight predominance of the subspecies Apis mellifera carnica (Table 1). Fig. 2 shows that the points corresponding to the samples of the area under study were intercepted with the ellipses of the subspecies mentioned above.

There was evidence of hybridization between the subspecies Apis mellifera ligustica and Apis mellifera carnica in La Estrella and Marchigue counties. This was because the venous branches of the studied wings had Mahalanobis distances that were close to these subspecies and also very similar between them, with a slight dominance for the subspecies Apis mellifera ligustica (Table 1) (Fig. 3a; 3b).

In the Paredones, Pichilemu, and Navidad counties, the wing venation patterns of the samples collected with the subspecies compared by GM indicated that there was hybridization between the subspecies Apis mellifera carnica and Apis mellifera ligustica, with a slight difference between the Mahalanobis distances, indicating a minimum dominance for Apis mellifera carnica. (Table 1) (Fig. 3c; 3d; 3e).

\section{DISCUSSION}

The introduction of populations of subspecies Apis mellifera carnica to Chile occurred in the 1980s (Rey and Díaz, 2007) but continues to the present (ProChile, 2018). Therefore, the genetic structure of honey bee populations in Chile and other countries is a dynamic process, depending on many factors, such as the preferential use of genetics lines, artificial selection, and the natural flow of genes between populations. For instance, the reported presence of Apis mellifera ligustica at a national level in previous studies (Del Lama et al., 2004; Vidal, 2012), remains an important lineage, but hybridization was demonstrated between both subspecies with a slight dominance by Apis mellifera carnica at the local level (county). Consequently, a change in genetic pattern has developed in the area, characterized by the initial introduction of the subspecies Apis mellifera mellifera (Padilla et al., 1992) followed by the use of the subspecies Apis mellifera ligustica (Padilla et al., 1992).

Currently, according to the records described by ProChile in 2018 and those obtained in this study, the change is also characterized by the strong presence of Apis mellifera carnica, which could be extrapolated to the regional and

Table 1. Mahalanobis distances found for the dry coastal zone of the O'Higgins Region and its counties.

\begin{tabular}{lcccccc}
\hline $\begin{array}{l}\text { Coastal zone } \\
\text { and counties }\end{array}$ & $\begin{array}{c}{ }^{a} \text { Apis } \\
\text { mellifera } \\
\text { carnica }\end{array}$ & $\begin{array}{c}{ }^{a} \text { Apis } \\
\text { mellifera } \\
\text { iberica }\end{array}$ & $\begin{array}{c}{ }^{a} \text { Apis } \\
\text { mellifera } \\
\text { intermissa }\end{array}$ & $\begin{array}{c}{ }^{a} \text { Apis } \\
\text { mellifera } \\
\text { ligustica }\end{array}$ & $\begin{array}{c}{ }^{a} \text { Apis } \\
\text { mellifera } \\
\text { mellifera }\end{array}$ & $\begin{array}{c}{ }^{a} \text { Apis } \\
\text { mellifera } \\
\text { scutellata }\end{array}$ \\
\hline Coastal dryland & 3.7687 & 8.2255 & 6.2837 & 3.7868 & 6.3020 & 5.9172 \\
La Estrella & 4.0898 & 7.9904 & 6.1297 & 3.7654 & 6.4358 & 5.7622 \\
Paredones & 4.4440 & 8.1817 & 6.6065 & 4.7099 & 6.6901 & 6.2234 \\
Pichilemu & 4.3141 & 8.5359 & 6.2271 & 4.4672 & 6.6751 & 5.8367 \\
Navidad & 4.1148 & 8.0196 & 5.9014 & 4.4471 & 5.8788 & 5.6958 \\
Marchigüe & 4.3046 & 8.7566 & 6.3841 & 4.1773 & 6.5899 & 5.7904 \\
\hline
\end{tabular}

Value of $\mathrm{p}<0.0001$

a: Subspecies of Apis mellifera.

Significant values by counties are marked in bold. 


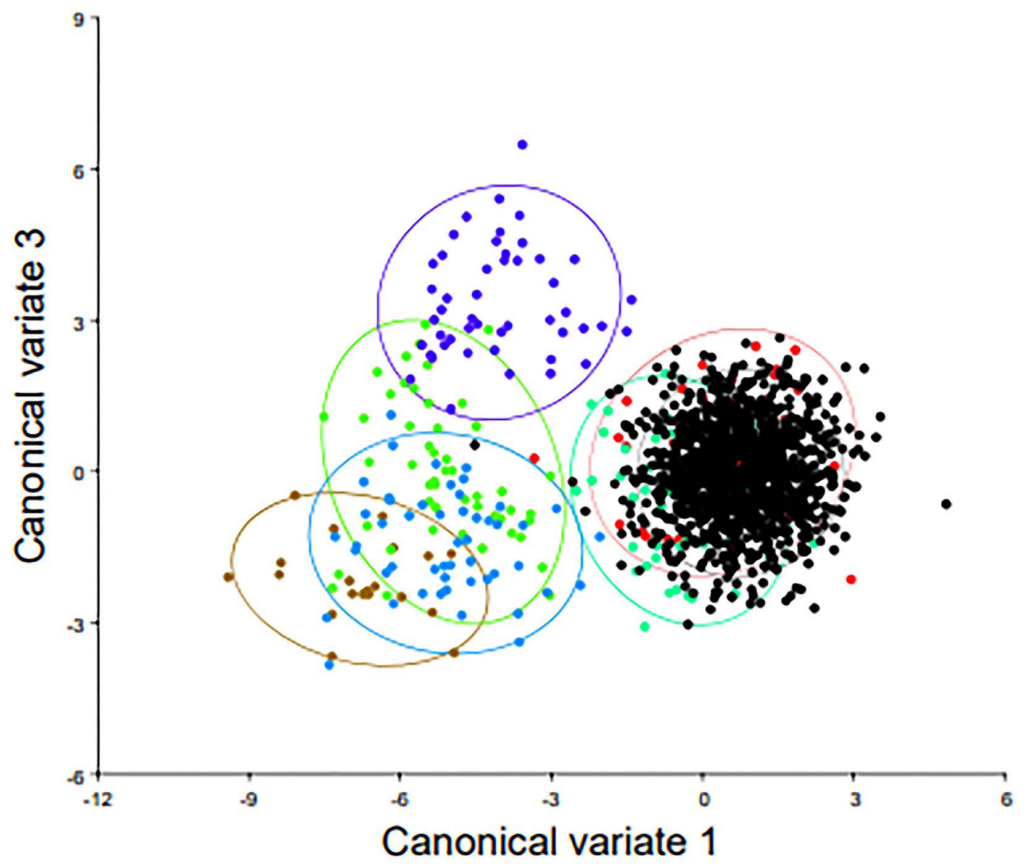

Fig. 2. Graph of canonical variables for the coastal zone of the $\mathrm{O}^{\prime}$ Higgins Region.

Red: Apis mellifera carnica; brown: Apis mellifera iberica; green: Apis mellifera intermissa; light blue: Apis mellifera ligustica; blue: Apis mellifera mellifera; purple: Apis mellifera scutellata; black: coastal area of the $\mathrm{O}^{\prime}$ Higgins Region.

national level. Even when the hybridization is a natural process, it is exacerbated by anthropic management in the area, driven by the high demand for honey bee genetic material in Canada, given that Chile produces bees that are highly resistant and capable of facing ecological conditions similar to those endured by bees bred in North America (ProChile, 2018). As a result, the breeding of subspecies and their hybrids is encouraged, and local beekeepers make use of what is available to them. However, regardless of the large market and exportation business of queens in Chile, it is worth questioning whether the introduction of this subspecies is appropriate for the area. Its entry generated a strong hybridization process with the subspecies previously present in the country (Del Lama, 2004; Vidal, 2012) and was initially characterized as unsuitable for both Mediterranean and cold climates (Ruttner, 1988; Susnik, 2004; SAG, 2018).

Although honey bee introduction was not by chance, as it sought to improve the international trade of queens to Canada and increase stocks, it could lead to detrimental situations for local beekeeping such as the decline in honey production as registered by ODEPA in 2018, and to informally registered losses of bee colonies. This could be because the performance of each subspecies is better if it is associated with a climate that is similar to that of its origins (Büchler et al, 2014; Taha and Al Kahtani, 2017; SAG, 2018). It suggests the necessity of different management plans since queen breeders are the ones who commercialize the genetic material among beekeepers and rely on a productive system for Apis mellifera ligustica, which are better adapted to the climate of central Chile (SAG, 2018).

ProChile, in its 2018 study of the beekeeping market in Canada, mentioned that a weakness in Chile is that offers pure subspecies, but according to them, a mixture of races is desirable and necessary. Such analysis is contrary to the results obtained in the present study, which indicates that there is a strong hybridization between A.m. ligustica and A.m. carnica, at least in the coastal zone of the $\mathrm{O}^{\prime}$ Higgins Region. Therefore, it is crucial to analyze genetic diversity quickly and use inexpensive tools to have a better criterion when selecting a colony for reproduction and commercialization of queens. Therefore, GM could be used by queen breeders and scientists (Bouga et al., 2011) to understand the lineages and races being produced, as it is a low-cost and easily accessible tool (Tofilski, 2008, Barour et al., 2011). Queen breeders might monitor and evaluate some productive parameters to 

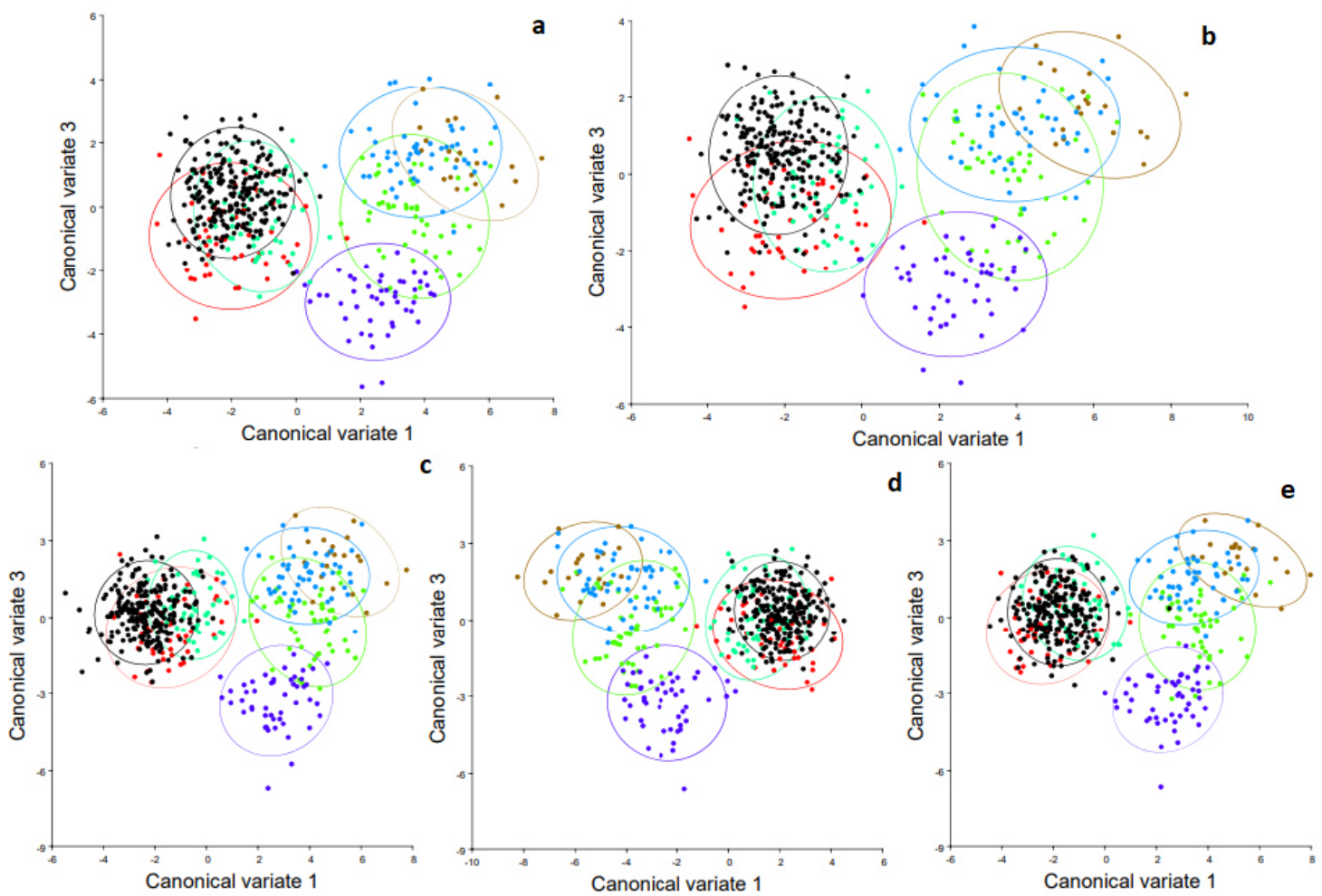

Fig. 3. Graph of canonical variables for the counties in the coastal zone of the O'Higgins Region. a) La Estrella; b) Marchigue; c) Paredones; d) Pichilemu; e) Navidad.

Red: Apis mellifera carnica; brown: Apis mellifera iberica; green: Apis mellifera intermissa; light blue: Apis. mellifera ligustica; blue: Apis mellifera mellifera; purple: Apis mellifera scutellata; black: counties in the coastal zone of the O'Higgins Region.

understand how bee populations with different degrees of hybridization perform in different regions and how different traits are inherited from one selected generation to the next one. This could add value to the sale of biological material by queen breeders as recommended by ODEPA in 2015, thereby improving the marketing of biological material at a national level that is suitable for the area, while also providing confirmation to the main importing country of Chilean queens that the present genetics is a mixture of subspecies as they prefer.

Furthermore, ProChile (2018) mentioned that the export markets that the country serves could be safeguarded through the registration of beekeepers that breed queens with the knowledge of the genetics they commercialize. To that end, GM could be used in the region since it has an ideal Mediterranean climate for beekeeping (Morse, 1994). The dry coastal zone of the O'Higgins Region could become an area of importance for queen breeding since it is currently characterized for having a low level of professional beekeeping, which adds to the low production of honey due to the lack of available nectar flow. In this way, the sale of queens could be expanded using genetics that are suitable both for local production and the commercialization of biological material at an international level. In this sense, it would be necessary to work together with queen breeders to evaluate the genetic lines they currently use, as well as their origin and traceability, and to enhance the value of those that present a better performance locally.

According to Del Lama et al. (2004) and Vidal (2012), the presence of Apis mellifera mellifera was common in Chile and throughout its regions, except for the extreme south zone, which was not sampled. However, in the sampled zone, no pattern was found in wing veins that were similar to the mentioned subspecies. This may be due to a declining presence of this subspecies through the dilution of its genetics against the Apis mellifera carnica subspecies, or just to the fact that the sampled zone was much smaller compared to the studies conducted by the abovementioned 
authors, who covered a much broader sampling zone. For this reason, it would be interesting to conduct national studies that assess the genetic dynamics of honey bee populations using molecular techniques complemented with GM. This would optimize management plans by associating the appropriate subspecies of honey bees to the most favorable zones, while improving production and survival rates in the area.

\section{CONCLUSIONS}

The present study provides a genetic characterization based on the study of honey bee wings by using geometric morphometric, in the dry coastal zone of one of the most important apicultural region of Chile. At the country level, this is the first study on the genetics of honey bees using GM. A significant presence of Apis mellifera carnica and its hybrids were found, which could be a matter of preference by local queen breeders because of the demands for this race from the Canadian market. It may be inferred that the genetic pattern for the region and the country could be changing. Therefore, further studies are required to estimate how this genetic variation affects productivity and survival of honey bee colonies with respect to historical records.

\section{ACKNOWLEDGMENTS}

We thank the beekeepers of the dry coastal zone of the O'Higgins Region for cooperating with this study, and for allowing us to sample and analyze their honey bee colonies.

We are grateful to the Vice-Rector of Research of the Mayor University for financial support to this study through the Fondo de Desarrollo a la Publicación (FDP, 2018).

\section{LITERATURE CITED}

Barour, C., A. Tahar, and M. Baylac. 2011. Forewing shape variation in Algerian honey bee populations of Apis mellifera intermissa (Buttel-Reepen, 1906) (Hymenoptera: Apidae): A landmark-based geometric morphometric analysis. Entomological Society of Southern Africa 19:11-22 doi:10.4001/003.019.0101

Bouga, M., C. Alaux, M. Bienkowska, R. Büchler, L. Norman, and E. Cauia, et al. 2011. A review of methods for discrimination of honey bee populations as applied to European beekeeping. Journal of Beekeeping Research 50:51-84 doi:10.3896/IBRA.1.50.1.06
Büchler, R., C. Costa, F. Hatjina, S. Andonov, M.D. Meixner, Y.L. Conte, et al. 2014. The influence of genetic origin and its interaction with environmental effects on the survival of Apis mellifera L. colonies in Europe. Journal of Apicultural Research 53:205-214. doi: 10.3896 / IBRA.1.53.2.03

Del Lama, M., R. Souza, X Duran, and A. Soares. 2004. Clinal variation and selection on MDH allozymes in honeybees in Chile. Hereditas 140:149-153.

De la Rúa, P., R. Jaffé, R. Dall'Olio, I. Muñoz, and J. Serrano. 2009. Biodiversity, conservation and current threats to European honeybees. Apidologie 40:263-284. doi: 10.1051 / apido / 2009027

Dogantzis, K., and A. Zayed. 2019. Recent advances in population and quantitative genomics of honey bees. Science Direct 31:93-98.

Franck P., L., M, Garnery, M. Solignac, and J-M. Cornuet. 2000. Molecular confirmation of a fourth lineage in honeybees from the Near East. Apidologie 31:167-180.

Klingenberg, C. 2011. MorphoJ: an integrated software package for geometric morphometrics. Mol. Ecol. Resour. 11:353357.

Miguel, I., M. Baylac, M. Iriondo, C. Manzano, L. Garnery, and A. Estonba. 2010. Both geometric morphometric and microsatellite data consistently support the differentiation of the Apis mellifera M evolutionary branch. Apidologie 42:150-161 doi: 10.1051/ apido/2010048

Morse R. 1994. Rearing Queen Honey Bees. Wicwas Press, Cheshire, USA.

ODEPA. 2013. Situación mundial de la producción y exportación de material vivo apícola. Oficina de Estudios y Políticas Agrarias (ODEPA), Santiago, Chile. Disponible en: http://www.agrimundo.gob.cl/wp-content/ uploads/131111_reporte_apicultura_n3.pdf (Consultado 02 de enero del 2019)

ODEPA. 2015. Informe Final. Estudio Estratégico de la Cadena Apícola de Chile. Oficina de Estudios y Políticas Agrarias (ODEPA), Santiago, Chile. Disponible en: https://www. indap.gob.cl/docs/default-source/descargasagricultura-familiarcampesina/uchile asagrin_2015_cadenaapicola.pdf?sfvrsn=2 (Consultado 02 de enero del 2019)

ODEPA. 2018. Apicultura Chilena: Actualización de mercado y estadísticas sectoriales, Octubre 2018. Oficina de Estudios y Políticas Agrarias (ODEPA), Santiago, Chile. Disponible en: https://www.odepa.gob.cl/wp-content/ uploads/2018/10/articulo-miel_octubre-1.pdf (Consultado 10 de enero del 2019) 
Oleksa, A., A. Tofilski. 2014. Wing geometric morphometrics and microsatellite analysis provide similar discrimination of honey bee subspecies. Apidologie 46:49-60. doi:10.1007/ s13592-014-0300-7.

Padilla, F., M. Bustos, J. Flores, and F. Puerta. 1992. Bees, beekeeping and the new world. ResearchGate 41:564.

PROCHILE. 2018. Estudio de mercado apícola en Canadá. Ministerio de Relaciones Exteriores Santiago, Chile. Disponible en: https://www. prochile.gob.cl/wp-content/uploads/2018/07/ pmp_apicola_canada_2018.pdf (Consultado 12 de enero del 2019)

OIE. 2019. Database of the World Animal Health Information System (WAHIS Interface). World Organization for Animal Health (OIE), Paris France. Available in: https://www. oie.int/es/sanidad-animal-en-el-mundo/elsistema-mundial-de-informacion-sanitaria/ datos-despues-2004-wahid/

(Accessed February 10, 2019)

Rey, F., and M. Díaz. 2007. Inicios, avances y proyecciones en mejoramiento y selección de abejas melíferas en Chile. Agro Sur 35:50-51.

Ruttner, F. 1988. Biogeography and taxonomy of honey bees. Springer, New York, USA.

SAG. 2018. Manual de Gestión ProductivaSanitaria y de Buenas Prácticas Apícolas. Servicio Agrícola y Ganadero (SAG), Santiago, Chile. Disponible en: http:// www.sag.gov.cl/sites/default/files/manual_ gestion_productiva-sanitaria_apicolasag-2018.pdf (Consultado 18 de febrero del 2019)
SAG. 2019. Boletín apícola N 4 . Servicio Agrícola y Ganadero (SAG), Santiago, Chile. Disponible en http://www.sag.cl/sites/default/files/ boletin_apicola_traza_4mz-vs-jn-2019.pdf (Consultado 18 de febrero del 2019)

Susnik, S., P. Kozmus, J. Poklukar, and V. Megli. 2004. Molecular characterization of indigenous Apis mellifera carnica in Slovenia. Apidologie 35:623-636.

Taha, E., and S. AL-Kahtani. 2017. Comparison of the activity and productivity of Carniolan (Apis mellifera carnica Pollmann) and Yemeni (Apis mellifera jemenitica Ruttner) subspecies under environmental conditions of the Al-Ahsa oasis of eastern Saudi Arabia. Saudi Journal of Biological Sciences 26:681687. doi: 10.1016/j.sjbs.2017.10.009

Tofilski, A. 2008. Using geometric morphometrics and standard morphometry to discriminate three honeybee subspecies. Apidologie 39:558-563. doi: 10.1051/apido:2008037

Toro, M., G. Manriquez, and I. Suazo. 2010. Morfometría geométrica y el estudio de las formas biológicas: de la morfología descriptiva a la morfología cuantitativa. International Journal of Morphology 28:997990. doi: 10.4067/S0717-95022010000400001

Vidal M. 2012. Análisis de la estructura genética de la población de abejas melíferas (Apis mellifera L.) de Chile: identificación de africanización utilizando biomarcadores de DNA mitocondrial. Tesis para optar al grado de Magister en Ciencias Médicas, mención de Biología Celular y Molecular, Universidad de Valparaíso, Valparaíso, Chile. 